\title{
Tata Kelola Teknologi Informasi Dengan Kerangka Kerja COBIT 5 Pada Lembaga Pemerintah dan Swasta
}

\author{
Ida Bagus Agung Eka Mandala Putra ${ }^{1}$, Nyoman Gunantara ${ }^{2}$, Made Sudarma ${ }^{3}$
}

[Submission: 28-12-2020, Accepted:01-02-2021]

\begin{abstract}
Information technology governance is an integral component of organizational control that includes organizational structure, information technology, and business strategies within the organization. Information technology governance is oriented in emphasizing the use of information technology in organizations to be useful and able to contribute to achieving organizational goals. To know the application of information technology governance, it is said to be good, it is necessary to assess to determine the ability of information technology governance in aligning business strategies with information technology processes. COBIT 5 is a comprehensive framework and can help (governance) management and (management) management in obtaining the goals of the organization/company. This study aims to determine the application of the COBIT 5 framework to measure the maturity level of information technology governance in institutions or organizations in Indonesia. It was found that COBIT 5 has been applied to various types of organizations such as private companies, government agencies, hospital agencies, and educational institutions. The average government and health institutions expect to achieve capability level 5 to get the optimal process, while the average achievement level capability is at level 3 with a value of 2 . Therefore, it is necessary to provide recommendations for improvement to achieve expectations at capability level 5 . Therefore, the purpose of this study is to review research related to the application of COBIT 5 in measuring the maturity level of information technology governance in companies, government agencies, hospitals, and educational institutions.
\end{abstract}

Keywords: Information Technology Governance, COBIT 5, Framework, Government, Private

Intisari- Tata kelola teknologi informasi adalah komponen integral pada pengendalian organisasi yang mencakup struktur organisasi, teknologi informasi beserta strategi bisnis dalam organisasi. Tata kelola teknologi informasi berorientasi dalam menegaskan pemanfaatan teknologi informasi pada organisasi menjadi berguna dan mampu berkontribusi untuk mencapai tujuan organisasi. Untuk mengetahui penerapan tata kelola teknologi informasi dikatakan baik perlu dilaksanakan penilaian untuk mengetahui kemampuan tata kelola teknologi informasi dalam menyelaraskan antara strategi bisnis dengan proses teknologi informasi. COBIT 5 merupakan suatu kerangka kerja

${ }^{1}$ Mahasiswa, Program Pasca Sarjana, Manajemen Sistem Informasi dan Komputer Fakultas Teknik Universitas Udayana, Jln. P.B. Sudirman, Denpasar, Bali 80232 INDONESIA (tlp: 0361-239599; e-mail: eka.mandala@student.unud.ac.id)

2, 3, ${ }^{4}$ Dosen, Program Studi Magister Teknik Elektro Fakultas Teknik Universitas Udayana, Jln. P.B. Sudirman, Denpasar, Bali 80232 INDONESIA (telp: 0361-239599 e-mail: gunantara@unud.ac.id,msudarma@unud.ac.id) secara menyeluruh dan mampu membantu (governance) tata kelola dan (management) manajemen dalam memperoleh tujuan organisasi/perusahaan. Penelitian ini bertujuan untuk mengetahui penerapan kerangka kerja COBIT 5 untuk mengukur tingkat kematangan tata kelola teknologi informasi pada lembaga atau organisasi di Indonesia. Ditemukan bahwa COBIT 5 telah diterapkan pada berbagai jenis organisasi seperti perusahaan swasta, instansi pemerintah, instansi rumah sakit dan instansi pendidikan. Adapun rata rata lembaga pemerintah dan kesehatan berharap dapat mencapai capability level 5 untuk mendapatkan proses yang optimal, sedangkan rata-rata pencapaian capability level berada pada level 3 dengan kesejangan bernilai 2 . Oleh sebab itu perlu diberikan rekomendasi perbaikan untuk mencapai harapan berada pada capability level 5. Maka dari itu, tujuan dari penelitian ini adalah mereview penelitian yang berhubungan dengan penerapan COBIT 5 dalam mengukur tingkat kematangan tata kelola teknologi informasi pada perusahaan, instansi pemerintah, intansi rumah sakit dan instansi pendidikan.

Kata Kunci- Tata Kelola Teknologi Informasi, Kerangka Kerja, COBIT 5, Pemerintah, Swasta

\section{Pendahuluan}

Teknologi informasi dan komunikasi adalah semua kegiatan yang berkaitan dengan pemrosesan, pengelolaan, dan penyampaian atau transfer informasi antar media [1]. Perkembangan teknologi dan informasi telah mempermudah dan mempercepat komunikasi melalui sarana yang tersedia tanpa batasan ruang dan waktu. Adanya teknologi informasi dapat menyelesaikan suatu masalah, meningkatkan efisiensi dan efektifitas aktivitas, serta membuka kreativitas manusia. Fitur teknologi informasi meliputi pengumpulan, pemrosesan, pembangkitan, penyimpanan, pengambilan, dan transmisi. Fungsi teknologi informasi mencakup sebagai penangkap, pengolah (processing), menghasilkan (generating), penyimpan (storage), pencari kembali (retrieval) dan sebagai transmisi atau transmission. Teknologi sebagai penangkap dimana mampu mengambil data berupa informasi yang berfungsi dalam aktifitas manusia.

Teknologi sebagai pengolah yaitu mengkompilasikan catatan aktifitas serta mengolah data yang diterima untuk memperoleh informasi. Teknologi sebagai produksi atau organisasi dalam bentuk yang bermanfaat seperti tabel, laporan dan grafik. Teknologi informasi sebagai penyimpanan dapat menyimpan data dan informasi dalam suatu sumber daya yang dapat digunakan untuk tujuan tertentu. Teknologi sebagai pencari kembali berfungsi untuk melacak, mengambil informasi dan menyalin data ke informasi yang sudah tersimpan. Teknologi sebagai transmisi mampu mengirimkan 
data dan informasi dari lokasi lain dengan menggunakan perantara jaringan komputer [2].

Tata kelola teknologi informasi adalah kewenangan dan tanggung jawab yang baik untuk mengambil keputusan dengan mendorong pemanfaatan teknologi informasi dalam suatu instansi. Pemanfaatan tata kelola teknologi infomasi terjadi berdasarkan hal serius (critical) pada operasional suatu organisasi. Pada struktur sistem tata kelola teknologi terdiri dari beberapa komponen yang meliputi aktifitas manusia, kendali dan regulasi. Adapun peran manusia dalam hal ini bertindak sebagai perancang, pembuat keputusan, pelaksana dan pengevaluasi sistem tata kelola teknologi informasi [3]. Beberapa kerangka kerja yang biasa digunakan dalam mengaudit sistem informasi suatu organisasi/lembaga adalah TOGAF, PMBOK/PRINCE2, ITIL V3, ISO/IEC31000, ISO/IEC 27000. Paling tidak ada sembilan yang dikenal secara luas yang terintegrasi dan menjadi bagian tidak terpisahkan dengan COBIT 5. COBIT 5 adalah kerangka kerja lengkap untuk membantu instansi mencapai tata kelola teknologi informasi dan tujuan regulasi di instansi tersebut. Pada praktiknya, COBIT memberikan panduan standar untuk membantu organisasi mencapai tujuannya melalui penggunaan teknologi informasi [4].

COBIT dikembangkan oleh Asosiasi Audit dan Kontrol Sistem Informasi atau disebut dengan ISACA. Sejarah awal mula COBIT 1 tahun 1998 dengan ruang lingkup kerangka kerja audit. Kemudian COBIT 2 pada tahun 1998 ruang lingkup kerangka kerja control. Selanjutnya COBIT 3 pada tahun 2000 dengan ruang lingkup kerangka kerja management. Tahun 2005 hadir COBIT 4 dan tahun 2007 hadir kembali dengan COBIT 4.1 dengan ruang lingkup IT Governance. Pengembangan versi terbaru dari COBIT yaitu COBIT 5 hadir tahun 2012 dengan mengkombinasikan COBIT 4.1, Val IT 2.0 serta Risk IT merupakan pengembangan strategis yang menyajikan pedoman berkaitan dengan tata kelola dan manajemen [5]. Perkembangan kerangka kerja COBIT dari awal sampai dengan versi terbaru menyesuaikan dengan perkembangan teknologi informasi, dan penyempurnaan dari versi-versi sebelumya.

Untuk menciptakan tata kelola pemerintahan yang baik, Pemerintah RI mengeluarkan Peraturan Presiden RI No.95/2018 tentang Sistem Pemerintahan Berbasis Elektronik (SPBE). Regulasi tersebut menyebabkan pemerintahan pusat serta pemerintahan daerah menerapkan SPBE untuk menciptakan manajemen pemerintah yang efektif, akuntabel, bersih, dan transparan. Serta memberikan pelayanan publik yang memiliki kualitas tinggi serta terpercaya [6]. Untuk memastikan kualitas penerapan SPBE berjalan dengan optimal diperlukan suatu audit dan evaluasi sesuai dengan standar yang ditetapkan.

Tujuan dari penelitian ini yaitu mereview penelitian yang berhubungan dengan penerapan COBIT 5 untuk mengukur tingkat kematangan dalam mengelola teknologi informasi pada perusahaan, instansi pemerintah, intansi rumah sakit dan instansi pendidikan. Penelitian ini memberikan informasi tentang bagaimana penerapan COBIT 5 dalam organisasi/lembaga untuk meningkatkan kinerja tata kelola teknologi informasi, dan juga memberi gambaran tentang bagaimana keberhasilan penerapan pengelolaan teknologi informasi di Indonesia.

\section{TinjauAn PustakA}

\section{A. Tata Kelola Teknologi Informasi}

Tata kelola teknologi informasi yaitu komponen yang terintegrasi dari pengendalian organisasi, termasuk struktur organisasi, teknologi informasi beserta strategi bisnis dalam organisasi. Pengelolaan teknologi informasi berorientasi untuk menegaskan pemanfaatan teknologi informasi pada organisasi menjadi berguna dan mampu berkontribusi untuk mencapai tujuan organisasi. Penerapan dalam mengelola teknologi informasi dengan baik memiliki tujuan untuk dapat menyeimbangkan teknologi informasi serta strategi bisnis. Tata kelola teknologi informasi memiliki peranan memungkinkan organisasi dalam mengambil keputusan dan memaksimalkan kegunaan implementasi teknologi informasi [7]. Terdapat beberapa bagian sumber daya utama informasi yang diperoleh dari teknologi informasi sebagai berikut yaitu aplikasi, informasi, infrastruktur manusia sebagai user [8].

\section{B. COBIT 5}

COBIT 5 adalah sebuah kerangka kerja yang secara menyeluruh dan mampu membantu (governance) tata kelola dan (management) manajemen dalam memperoleh tujuan organisasi/perusahaan [4]. Suatu kerangka kerja mampu mengoptimalkan kualitas teknologi informasi, menyelaraskan antara manfaat dari teknologi informasi dalam tingkat resiko beserta pendayagunaan sumber daya. Dalam COBIT 5 disediakan pengelolaan atas IT dengan menyeluruh serta komitmen perusahaan dari ujung-ke-ujung dan manfaat teknologi informasi, serta memperhitungkan berkaitan atas kepentingan teknologi informasi pada sisi penyelenggara kepentingan internal maupun eksternal [4].

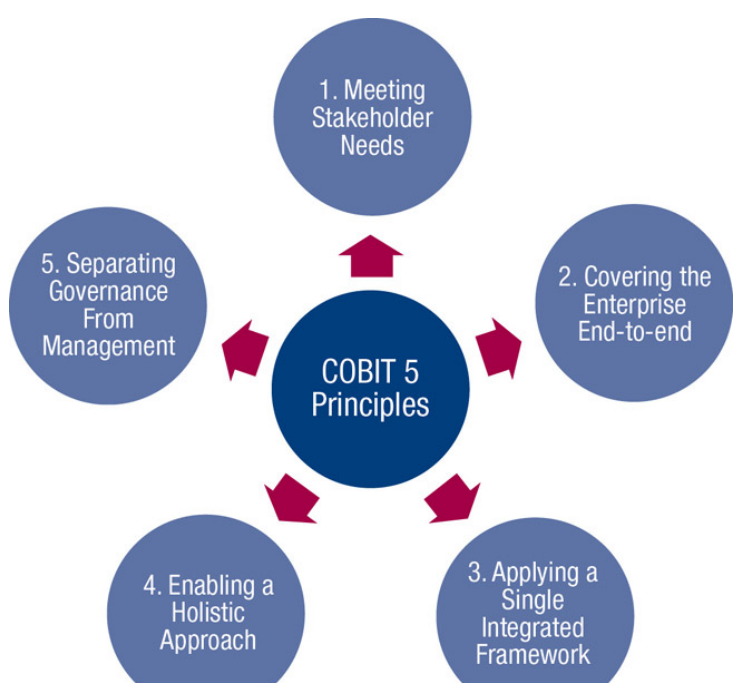

Gambar 1. Lima Prinsip COBIT 5 (ISACA 2012) [4]

Pada proses COBIT 5 dibedakan menjadi dua domain, yaitu prosedur tata kelola dari Evaluation, Direct dan Monitoring atau disingkat dengan EDM. Sedangkan manajemen terdapat empat domain DSS, BAI, APO, dan MEA secara keseluruhan pada COBIT 5 terdapat sebanyak 
DOI: https://doi.org/10.24843/MITE.2021.v20i01.P01

tiga puluh tujuh domain proses teknologi informasi [9]. Pada rangkaian COBIT 5 terdapat proses capability level, dengan berdasarkan kriteria ISO/IEC 15504 Software Engineering Process Assessment Standard. Dalam capability level terdapat enam tingkat suatu pencapaian, diawali dari 0 sampai dengan 5. Tahapan pencapaian akan disesuaikan dan ditentukan dari hasil penilaian pada domain-domain yang dipergunakan [4].

TABEL I

CAPABILITY MODEL (ISACA 2012) [4]

\begin{tabular}{|l|l|}
\hline Tingkatan & Deskripsi \\
\hline $\begin{array}{l}\text { Level 0: } \\
\text { Proses } \\
\text { menunjukan } \\
\text { tidak lengkap }\end{array}$ & $\begin{array}{l}\text { Prosedur tidak diaplikasikan atau dapat } \\
\text { dinyatakan gagal untuk mencapai target }\end{array}$ \\
\hline $\begin{array}{l}\text { Level 1: } \\
\text { Proses } \\
\text { dijalankan }\end{array}$ & $\begin{array}{l}\text { Prosedur yang diaplikasikan berhasil } \\
\text { memperoleh tujuan }\end{array}$ \\
\hline $\begin{array}{l}\text { Level 2: } \\
\text { Prosedur } \\
\text { menunjukan } \\
\text { terkelola }\end{array}$ & $\begin{array}{l}\text { Prosedur yang sudah dijalankan dan diterapkan } \\
\text { secara teratur (direncanakan, ditinjau dan } \\
\text { disesuaikan) dengan hasil kerja telah } \\
\text { ditentukan, dikendalikan dan dipelihara dengan } \\
\text { tepat. }\end{array}$ \\
\hline $\begin{array}{l}\text { Level 3: } \\
\text { Menerangkan } \\
\text { proses mulai } \\
\text { terbentuk }\end{array}$ & $\begin{array}{l}\text { Pengelolaan proses sebelumnya telah } \\
\text { diaplikasikan menggunakan prosedur yang } \\
\text { sudah ditetapkan, yang dapat memperoleh hasil } \\
\text { proses yang diharapkan. }\end{array}$ \\
\hline $\begin{array}{l}\text { Level 4: } \\
\text { Prosedur yang } \\
\text { mampu } \\
\text { diprediksi }\end{array}$ & $\begin{array}{l}\text { Prosedur dibangun sebelumnya sudah } \\
\text { beroperasi pada batasan yang ditentukan untuk } \\
\text { memperoleh hasil proses yang diharapkan }\end{array}$ \\
\hline $\begin{array}{l}\text { Level 5: } \\
\text { Proses yang } \\
\text { optimal }\end{array}$ & $\begin{array}{l}\text { Prosedur yang mampu diprediksi sebelumnya } \\
\text { ditingkatkan secara berkesinambungan dalam } \\
\text { memenuhi orientasi bisnis saat ini dan di masa } \\
\text { depan }\end{array}$ \\
\hline
\end{tabular}

\section{Metodologi Penelitian}

Data yang digunakan dalam penelitian ini bersumber dari dokumen resmi pemerintah. Selain itu digunakan publikasi ilmiah yang diperoleh melalui Google Scholar. Skematik penelitian disajikan pada gambar 4 .

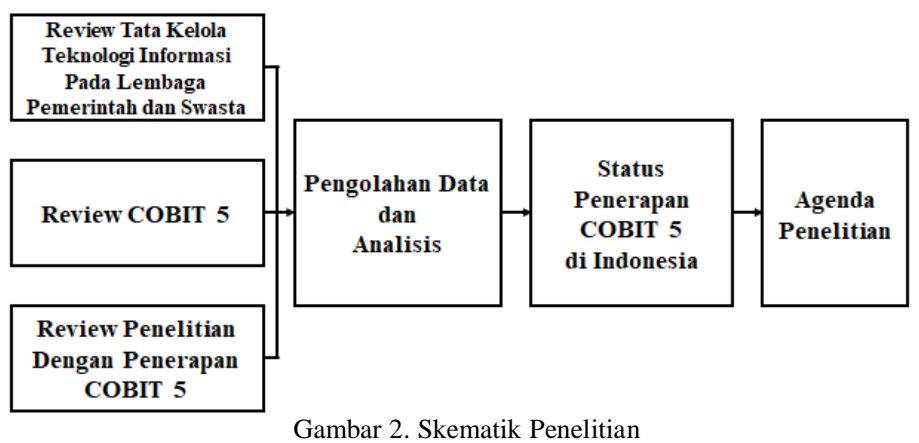

I.B.A.E.M. Putra : Tata Kelola Teknologi Informasi...
Berdasarkan skematik penelitian diatas, langkah-langkah yang dilakukan meliputi, mereview penerapan tata kelola teknologi pada lembaga pemerintah dan swasta untuk mengidentifikasi permasalahan yang terjadi. Pada tahap kedua melakukan review COBIT 5 untuk mempelajari mekanisme penerapan COBIT 5 pada lembaga pemerintah dan swasta. Tahap ketiga mereview penelitian yang menerapkan COBIT 5 untuk mengukur tingkat capability level teknologi informasi dalam suatu lembaga.

Selanjutnya pada tahap keempat mengolah data khususnya tingkat kematangan pada setiap instansi objek penelitian untuk mengetahui hasil audit COBIT 5 dan kebutuhan organisasi dalam menerapkan tata kelola teknologi informasi. Tahap kelima melakukan analisis dan melihat karakteristik hasil audit bagi lembaga pemerintah dan swasta yang menerapkan COBIT 5 di Indonesia. Pada tahap akhir akan dijelaskan secara singkat tentang rencana penerapan COBIT 5 untuk mengetahui tingkat kematangan dalam pengelolaan teknologi informasi pada salah satu OPD Pemerintah Kota Denpasar.

\section{IV.HASIL DAN PEMBAHASAN}

Telaah literature terhadap penerapan COBIT 5 untuk menilai tingkat kematangan suatu sistem teknologi informasi di Indonesia baru kelihatan ada sejak tahun 2013. Hal ini merupakan sesuatu yang wajar menimbang bahwa metode COBIT 5 baru dipublikasikan pada tahun 2012 oleh ISACA. Hasil telaah penelitian ini tentang COBIT 5 di Indonesia sampai tahun 2020 akan didiskusikan secara detail dibawah ini.

\section{A. Penelitian penerapan kerangka kerja COBIT 5}

Darmawan dan Harto (2019) melaksanakan penelitian penerapan COBIT 5 dalam analisis kualitas suatu layanan $E$ Government di Kabupaten Pamekasan pada bidang pemerintahan dengan fokus pada level manajemen. Penelitian ini menargetkan pencapaian capability level 4 (predictable process), prosedur dibangun sebelumnya sudah beroperasi pada batasan yang ditetapkan untuk memperoleh hasil yang diinginkan. Namun capability level proses teknologi informasi pada domain BAI bernilai 2.85 sehingga ada pada level 3 (established) dengan angka kesenjangan 1.15. Sementara domain DSS adalah 2.50 sehingga berada pada level 3 dengan nilai kesenjangan 1.5. Domain MEA dengan nilai 2.83 berada pada level 3 dengan tingkat kesenjangan 1.17. Tingkat kesenjangan tersebut menunjukan tingkat kematangan layanan E-Government belum mencapai tingkat kematangan manajemen yang diharapkan pada level 4 . Secara keseluruhan tata kelola layanan teknologi informasi Dispendukcapil Kabupaten Pamekasan menunjukan layanan sudah diimplementasikan berdasarkan standar layanan teknologi informasi yang ada. Saran yang diberikan untuk meningkatkan pencapaian capability level tata kelola layanan teknologi informasi, adalah dibutuhkan kewenangan paling banyak berada pada tingkatan kelurahan/desa serta kecamatan.

p-ISSN:1693 - 2951; e-ISSN: 2503-2372 
Selanjutnya memberikan SDM berkompeten pada bidang TI untuk layanan layanan e-government lebih bermutu [10].

Mustofa dan Handani (2017) menerapkan COBIT 5 untuk mengukur kinerja sistem penginformasian dalam mengelola keuangannya pada Kantor Kecamatan Kemranjen bidang pemerintahan dengan fokus pada level manajemen. Penelitian ini menetapkan target capability level 3 (established) menunjukan pengelolaan proses sebelumnya telah diaplikasikan menggunakan prosedur yang sudah ditetapkan, yang dapat memperoleh hasil proses yang diharapkan. Namun penilaian menunjukan domain MEA01, domain MEA02 serta domain MEA03 menunjukan pencapaian capability level 2 (managed process) dengan kesenjangan bernilai 1 dari target yang diharapkan. Menunjukan proses dilakukan telah diimplementasikan, dilaksanakan (perencanaan, monitor serta disesuaikan) dengan hasil proses ditentukan, dikendalikan serta pemeliharaan secara tepat. Rekomendasi dalam mencapai capability level harapan pada MEA01 adalah pegawai yang mengoperasikan serta memiliki tanggung jawab terhadap sistem harus mempunyai pelatihan serta pendidikan khusus. MEA02 kebutuhan sumber daya dalam mengoperasikan sistem wajib dipantau dan terdapat pemeliharan berkala dalam menjaga keakuratan sistem tersebut. MEA03 pihak instansi wajib mempunyai suatu pengukuran atau cakupan diterapkan pada sistem apabila terjadi kendala dapat langsung ditangani tanpa menganggu proses administrasi [11].

Hermawan dan Pahlevi (2019) menggunakan COBIT 5 mengevaluasi sistem pelayanan terpadu pada Kecamatan Jambi Timur sektor pemerintahan berfokus pada level manajemen. Penelitian bertujuan mengevaluasi sistem informasi pelayanan terpadu dengan menargetkan pencapaian capability level 4 (predictable process) pada domain DSS01 tentang pengelolaan operasi, DSS03 mengelola permasalahan, DSS04 tentang manage continuity. Menunjukan prosedur dibangun sebelumnya sudah beroperasi pada batasan yang ditentukan untuk memperoleh hasil proses yang diharapkan. Sedangkan DSS02 mengelola permintaan layanan serta insiden, DSS05 tentang mengelola layanan keamanan, DSS06 tentang mengelola kontrol proses bisnis ditargetkan pada level 3 (established process). Menunjukan pengelolaan proses sebelumnya telah diaplikasikan menggunakan prosedur yang sudah ditetapkan, yang dapat memperoleh hasil proses yang diharapkan. Selanjutnya hasil evaluasi sistem pelayanan terpadu menunjukan DSS01, DSS03 dan DSS04 berada pada level 3 yang artinya tidak mencapai target dengan kesenjangan bernilai 1. Untuk DSS02, DSS05 dan DSS06 telah mencapai capability level harapan. Secara keseluruhan tingkat pencapaian capability level sistem pelayanan terpadu terdapat dalam level 3 yang mengartikan bahwa proses mulai terbentuk dan sudah berjalan dengan produktif dan memadai dengan harapan stakeholder. Rekomendasi untuk mencapai capability level harapan dengan melaksanakan evaluasi tingkat kepuasan pengguna sistem pelayanan terpadu dengan rutin dan berkala. Melaksanakan suatu manajemen back-up dilakukan oleh pihak ketiga secara teratur. Menyusun hal-hal yang merupakan kelemahan pada manajemen perencanaan keberlangsungan prosedur bisnis [12].

Rehatta dan Manuputy (2019) melakukan pengukuran tingkat kematangan dalam mengelola teknologi informasi manajemen kepegawaian Badan Kepegawaian, Pelatihan serta Pendidikan di Daerah Kota Salatiga pada sektor pemerintah dengan COBIT 5 fokus pada level manajemen. Penelitian ini menilai tingkat kematangan pengelolaan teknologi informasi sesuai dengan assess, evaluate, and domain monitor, pada COBIT 5 menetapkan target capability level 5 (optimising process). Menunjukan proses terus ditingkatkan dengan berkelanjutan dalam memenuhi orientasi bisnis pada saat ini dan dimasa depan. Adapun hasil pengukuran menunjukan domain MEA01 bernilai 3.70 terdapat dalam capability level 4 (predictable process) dengan nilai kesenjangan 1.3 dari target. MEA02 bernilai 3.36 terdapat dalam capability level 3 (established process) nilai kesenjangan 1.64 dari target. MEA03 bernilai 3.55 terdapat dalam capability level 4 dengan nilai kesenjangan 1.45 dari target. Menunjukan bahwa rerata capability level terdapat dalam level 4, yang prosedur dibangun sebelumnya sudah beroperasi pada batasan yang ditentukan untuk memperoleh hasil proses yang diharapkan. Rekomendasi dalam mencapai capability level harapan dengan keseluruhan dalam evaluasi serta pengamatan kinerja sistem informasi manajemen kepegawaian secara rutin, menjalankan dokumentasi atas pemeliharaan tata kelola teknologi informasi beserta memberikan pendidikan dengan mengoptimalkan mutu sumber daya manusia [13].

Chairani dkk (2019) menggunakan COBIT 5 menganalisis pengelolaan teknologi informasi dalam peningkatan mutu SDM Dinas Ketenaga Kerjaan dan Transmigrasi Provinsi Nusa Tenggara Barat pada sektor pemerintahan fokus pada level manajemen. Penelitian ini menetapkan target pada capability level 4 (predictable process) yang artinya prosedur dibangun sebelumnya sudah beroperasi pada batasan yang ditentukan untuk memperoleh hasil proses yang diharapkan. Adapun hasil penelitian menunjukan domain APO01 dan APO02 hanya terdapat dalam capability level 2 (managed process) dengan kesenjangan bernilai 2 dari target. Kesimpulan dari capability level menjelaskan sebagian besar pada proses bisa diulang, namun tergantung terhadap pengetahuan individu, oleh karena itu probabilitas untuk terjadinya kesalahan cukup besar. Adapun inisiatif untuk pengendalian sumber daya manusia tetapi tidak adanya (standard operational procedure) SOP menjalankan proses tersebut. Rekomendasi dalam mencapai target capability level dengan melaksanakan pengembangan serta pemeliharan dengan rutin terkait ketersediaan sumber data teknologi informasi terhadap prosedur manajemen KKMTI supaya tujuan Disnakertrans NTB mampu beroperasi secara efektif. Menentukan solusi kesenjangan kapabilitas menegaskan kontrak petugas teknologi informasi dengan menandatangi serta menyetujui seluruh kesepakatan yang dibutuhkan [14].

Krisnandari dkk (2019) menerapkan teknologi informasi untuk reformasi birokrasi dalam bidang pendidikan fokus pada manajemen. Penelitian ini bertujuan mengidentifikasi dan memberikan saran terhadap jajaran birokrasi dalam menggunakan sistem pelayanan IMISSU dan menetapkan target capability level 4 (predictable process), yang artinya prosedur dibangun sebelumnya sudah beroperasi pada batasan yang ditentukan untuk memperoleh hasil proses yang diharapkan. Namun penelitian ini menunjukan nilai rata-rata MEA01 3.68, MEA02 3.58 dan MEA03 3.60 dengan capability level 3 (established process) dengan kesenjangan 
bernilai 1 pada setiap proses terhadap target capability level, menunjukan pengelolaan proses sebelumnya telah diaplikasikan menggunakan prosedur yang sudah ditetapkan, yang dapat memperoleh hasil proses yang diharapkan. Saran untuk mencapai capability level target dengan meningkatkan kinerja petugas untuk mengamalkan pelayanan secara efisien serta ramah lingkungan dalam memberikan suatu pelayanan. Mengoptimalkan sarana serta prasarana dalam pelayanan publik, sehingga mampu meningkatkan kenyamanan baik dari sisi yang memberikan pelayanan dan sisi yang menerima pelayanan. Memaksimalkan fasilitas teknologi informasi disediakan institusi dalam mendukung kinerja sistem dan petugas yang memberikan pelayanan [15].

Sumichan dkk (2018) memanfaatkan COBIT 5 dalam audit sistem informasi project management pada sektor bisnis dibidang kontraktor fokus pada level manajemen. Adapun tujuan penelitian ini adalah menganalisis permasalahan dalam perusahaan kontraktor PT. K dengan menetapkan target capability level 4 (predictable process) yang artinya prosedur yang dibangun sebelumnya sudah beroperasi pada batasan yang tetapkan untuk memperoleh hasil proses yang diinginkan. Hasil audit menunjukan DSS01 bernilai 86.25 terdapat pada capability level 3, DSS02 bernilai 88 berada pada capability level 3 kedua domain tersebut memiliki selisih kesenjangan bernilai 1 dalam mencapai target. Selanjutnya DSS06 bernilai 87.5 berada pada capability level 2 (managed process) selisih kesenjangan bernilai 2 dari target. Kemudian DSS03 bernilai 88.25 berada pada capability level 1 (performed process) selisih kesenjangan yang cukup tinggi benilai 3 dari target. Domain DSS04 bernilai 89 berada pada capability level 4 dan mencapai target yang diharapkan. Hasil audit menyimpulkan tata kelola teknologi informasi sudah diimplementasikan dengan cukup efektif walaupun masih mempunyai masalah. Berfokus pada nilai kesenjangan yang cukup tinggi pada domain DSS03, rekomendasi yang diberikan untuk mencapai capability level harapan dengan pembaharuan sistem dibutuhkan untuk mempermudah pengguna dalam mengakses sistem kapapun dan dimanapun [16].

Aji dan Sarmini (2019) melakukan penilaian terhadap tata kelola IT pada Dinas Kesehatan yang berada di Kabupaten Banyumas dengan memakai COBIT 5 fokus penilaian pada level manajemen. Penelitian bertujuan menilai penggunaan teknologi informasi dalam mengetahui teknologi informasi pada saat ini telah memenuhi target yang diharapkan oleh instansi terkait. Penelitian ini menetapkan target capability level 3 (established process) menunjukan pengelolaan proses sebelumnya telah diaplikasikan menggunakan prosedur yang sudah ditetapkan, yang dapat memperoleh hasil proses yang diharapkan. Adapun hasil penilaian pada domain DSS01, DSS03 dan DSS06 tidak mencapai target hanya terdapat dalam capability level 2 (managed process) dengan kesenjangan bernilai 1. Hasil ini menunjukan prosedur yang sudah dijalankan dan diterapkan secara teratur (direncanakan, ditinjau dan disesuaikan) dengan hasil kerja telah ditentukan, dikendalikan dan dipelihara

I.B.A.E.M. Putra : Tata Kelola Teknologi Informasi... dengan tepat. Adapun domain DSS02, DSS04 dan DSS05 telah mencapai target yang harapkan yang artinya tata kelola teknologi informasi telah sukses dalam mengimplementasikan proses dengan menggapai tujuannya, dan telah melakukannya dengan lebih teratur. Saran untuk mencapai capability level harapan yakni merealisasikan aturan secara tertulis selanjutnya didistribusikan untuk semua karyawan dalam mengontrol prosedur manage operation, prosedur manage problems, beserta prosedur manage business process controls sehingga berjalan secara maksimal [17].

Wijaya dan Andani (2017) mengevaluasi kinerja sistem informasi $e$-filling dengan COBIT 5 terkait dengan pelayanan perpajakan pada KPP Kota Salatiga dengan penekanan pada level manajemen. Penilaian ini bertujuan mengetahui tingkat pencapaian tujuan bisnis serta menilai tingkat kematangan sistem informasi $e$-filling dalam mencapai tujuan bisnis, pada domain APO13 dan DSS05 memiliki target capability level 3 (established process) yang artinya pengelolaan proses sebelumnya telah diaplikasikan menggunakan prosedur yang sudah ditetapkan, yang dapat memperoleh hasil proses yang diharapkan. Sedangkan domain BAI06 menetapkan target capability level 4 (predictable process) menunjukan prosedur dibangun sebelumnya sudah beroperasi pada batasan yang ditentukan untuk memperoleh hasil proses yang diharapkan. Hasil penilaian domain APO13 bernilai 0.55 berada pada capability level 1 (performed process) selisih kesenjangan bernilai 2 pada target, domain BAI06 bernilai 1.58 berada pada capability level 2 (managed process) selisih kesenjangan bernilai 2 dari target. Sedangkan domain DSS05 bernilai 1.52 berada pada capability level 2 dengan kesenjangan bernilai 1 dari target. Menunjukan bahwa sudah melakukan implementasi, namun tidak terdapat pengawasan dan perencanaan secara terstruktur. Temuan hasil audit menunjukan adanya masalah yang muncul berhubungan dengan sistem informasi e-filling yakni tidak adanya komunikasi didalam lingkup Kantor Pelayanan Pajak Pratama terkait keamanan sistem. Sehingga rekomendasi dalam mencapai capability level harapan dengan mengkomunikasikan antar pihak penanggung jawab pada instansi terkait yang memiliki wewenang terhadap penggunaan sistem informasi $e$-filling yaitu seksi PDI serta seksi pelayanan. Pentingnya komunikasi di internal Kantor Pelayanan Pajak Pratama agar para penanggung jawab Kantor Pelayanan Pajak Pratama memahami akan pentingnya mengelola keamanan sistem [18].

Rohman dkk (2020) menggunakan COBIT 5 dalam menganalisa pengelolaan teknologi informasi untuk meningkatkan tujuan pariwisata pada Dinas Pariwisata Propinsi Nusa Tenggara Barat, dengan fokus penelitian pada level manajemen. Penelitian ini memiliki target capability level 4 (predictable process) menunjukan prosedur dibangun sebelumnya sudah beroperasi pada batasan yang ditentukan untuk memperoleh hasil proses yang diharapkan. Adapun hasil penelitian menunjukan domain APO01 dan APO02 hanya terdapat dalam capability level 2 (managed process)

p-ISSN:1693 - 2951; e-ISSN: 2503-2372 
dengan kesenjangan bernilai 1 dari target. Hasil ini menunjukan prosedur yang sudah dijalankan dan diterapkan secara teratur (direncanakan, ditinjau dan disesuaikan) dengan hasil kerja telah ditentukan, dikendalikan dan dipelihara dengan tepat. Rekomendasi yang diberikan untuk mencapai target capability level dengan menerapkan kemajuan TI untuk keperluan yang akan datang berdasarkan standar yang sudah ditentukan. Melaksanakan pengembangan teknologi informasi sesuai tujuan [19].

Safriwal (2017) menerapkan COBIT 5 untuk memberikan kontribusi dalam perbaikan kepada manajemen IT pada sebuah Dinas Sosnakertrans yang berada pada Kabupaten Solok, dengan fokus pada level manajemen. Penelitian ini menargetkan terdapat dalam capability level 2 (managed process), yang artinya layanan diharapkan dapat mengelola proses teknologi informasi serta memenuhi layanan pengerjaan kartu pencari kerja (AK.1) memadai dengan jumlah pengguna dan stabil. Hasil penelitian ini menunjukan DSS01 terdapat dalam capability level 1 (performed process) dengan kesenjangan bernilai 1 dari target, yang artinya prosedur yang diaplikasikan berhasil memperoleh tujuan. Sedangkan DSS02, DSS03, DSS04 dan DSS05 terdapat dalam capability level 0 (incomplete process) dengan kesenjangan bernilai 2 dari target, yang artinya prosedur tidak diaplikasikan atau dapat dinyatakan gagal untuk mencapai target. Rekomendasi yang diberikan agar target capability level tercapai dengan melakukan implementasi dasar pengelolaan teknologi informasi pada setiap proses. Mempersiapkan tim yang dapat bekerja cepat untuk menyelesaikan masalah kinerja sistem [20].

Wahyuni (2017) menerapkan COBIT 5 untuk mengevaluasi perbaikan sistem informasi akademik pada STMIK Hang Tuah Pekan Baru, dengan fokus pada level manajemen. Penelitian ini memiliki target capability level 3 (established process) yang artinya pengelolaan proses sebelumnya telah diaplikasikan menggunakan prosedur yang sudah ditetapkan, yang dapat memperoleh hasil proses yang diharapkan. Adapun hasil penelitian menunjukan domain DSS01, DSS02, DSS03, DSS04, APO09, BAI04, dan BAI06 tidak mencapai target dengan rata-rata secara keseluruhan berada pada capability level 1 (performed process) serta kesenjangan bernilai 2 dari target. Hasil ini menunjukan sistem informasi akademik sudah dijalankan namun tidak secara maksimal. Rekomendasi yang diberikan untuk mencapai capability level harapan dengan menciptakan sistem monitoring beserta evaluasi yang efisien kepada proses yang terdapat pada sistem informasi dalam memaksimalkan keberlangsungan sistem. Mewujudkan dokumentasi terhadap hasil proses secara menyeluruh dan kesalahan yang terjadi dalam sistem informasi menjadi bahan pengevaluasian untuk pengembangan sistem kedepannya [21].

Doni dan Yusefni (2018) menggunakan COBIT 5 mengevaluasi manajemen perjanjian layanan SI akademik pada Poltekkes Kemenkes Padang, dengan fokus evaluasi pada level manajemen. Penelitian ini memiliki harapan capability level 3 (established process) yang artinya pengelolaan proses sebelumnya telah diaplikasikan menggunakan prosedur yang sudah ditetapkan, yang dapat memperoleh hasil proses yang diharapkan. Hasil penelitian menunjukan domain APO09 tidak mencapai harapan dengan berada pada capability level 1 (performed process). Hasil tersebut menyimpulkan terdapat pendekatan secara sistematis beserta pencapaian relevan terhadap proses tersebut walaupun terdapat kelemahan tidak signifikan. Saran yang diberikan untuk mencapai capability level harapan dibutuhkan pelaksanaan pemantauan serta evaluasi terhadap kebutuhan layanan teknologi informasi, pengawasan layanan teknologi informasi dan penambahan infrastruktur [22].

Thenu dkk (2020) menggunakan COBIT 5 untuk menganalisis manajemen resiko TI pada perusahaan PT. Global Infotech bergerak pada bidang solusi IT, dengan fokus pada level manajemen. Penelitian ini memiliki target terdapat dalam capability level 2 (managed process) yang mengartikan prosedur yang sudah dilaksanakan dan diterapkan secara teratur (direncanakan, ditinjau dan disesuaikan) dengan hasil kerja telah ditentukan, dikendalikan dan dipelihara dengan tepat. Namun hasil penelitian ini menunjukan domain APO12 terdapat dalam capability level 1 (performed process) menunjukan prosedur yang diaplikasikan berhasil memperoleh tujuannya, dengan status pencapaian largely achieved. Untuk mencapai target capability level tentunya diberikan rekomendasi perbaikan dengan mewujudkan suatu pengelolaan resiko untuk pengawasan terhadap manajemen resiko dilaksanakan dengan tepat. Merealisasikan dokumen berkaitan dengan identifikasi resiko dan skenario teknologi informasi yang tepat dalam upaya mitigasi terhadap resiko [23].

Penelitian selanjutnya penerapan COBIT 5 dengan fokus pada level tata kelola. Cahyani dkk (2019) merancang tata kelola IT dalam Sistem Pemerintahan secara Elektronik pada Dinas Komunikasi Informatika dan Statistik yang berada pada Kabupaten Bandung Barat dengan mengimplementasikan COBIT 5 fokus pada level tata kelola. Penelitian ini memiliki tujuan untuk memberi sebuah rekomendasi dalam penyusunan tata kelola teknologi informasi. Penelitian ini menghasilkan penilaian resiko proses pada EDM01 bernilai 1.82, EDM02 bernilai 5.27, EDM04 bernilai 2.45 dan EDM05 bernilai 0.27. Sehingga disimpulkan proses yang menjadi perioritas resiko tertinggi dalam merancang pengelolaan teknologi informasi pada proses EDM02 berhubungan atas investasi teknologi informasi. EDM03 berhubungan akan optimasi resiko dan proses EDM04 berhubungan atas optimasi sumber daya. Adapun rekomendasi yang diberikan dalam mengoptimalkan kondisi pengelolaan teknologi informasi sekarang ini dan meminimalisir resiko dengan menambahkan wewenang, tugas serta tanggung jawab terhadap formasi staf yang sudah ada pada saat ini. Menciptakan sebagian poin dalam pengaturan proses terdiri atas kebijakan dan standard operational procedure (SOP) [7].

Hariyono (2018) menggunakan COBIT 5 untuk menganalisis dan menilai teknologi informasi dalam proses tata kelola sektor instasi pendidikan Universitas Peradaban fokus pada level tata kelola. Penelitian bertujuan menilai dan menganalisis pengelolaan teknologi informasi pada domain EDM dengan target pencapaian fully achieved pada setiap tingkat capability level untuk mendapatkan hasil yang optimal. Adapun hasil penelitian ini menunjukan capability level largely achieved terdapat dalam capability level 1 (performed process) domain EDM01. Menunjukan bahwa kinerja proses tidak ada perencanaan tanpa pengawasan, tidak terdapat 
DOI: https://doi.org/10.24843/MITE.2021.v20i01.P01

proses identifikasi atas sumber daya serta informasi yang diperlukan untuk menjalankan proses. Rekomendasi ditawarkan untuk meningkatkan kapasitas level 1 agar dapat tercapai sepenuhnya, yaitu menciptakan jaminan bahwa pengelolaan teknologi informasi bekerja secara efektif. Penyusunan dokumentasi tentang perencanaan setiap kegiatan, implementasi dengan pemeliharaan teknologi informasi yang berkaitan dengan bisnis[24].

Rizal dan Rasmila (2015) menilai tata kelola IT RS. Kusta Dr. Rivai Abdullah Palembang dengan menggunakan COBIT 5 fokus pada level tata kelola. Penelitian ini memiliki harapan terdapat dalam capability level 3 (established process) yang artinya pengelolaan proses sebelumnya telah diaplikasikan menggunakan prosedur yang sudah ditetapkan, yang dapat memperoleh hasil proses yang diharapkan. Namun hasil penilaian menunjukan domain EDM01, EDM02, EDM03, EDM04 dan EDM05 terdapat dalam capability level 2 (managed process) dengan kesenjangan bernilai 1 dari harapan. Hasil tersebut menunjukan prosedur yang sudah dijalankan dan diterapkan secara teratur (direncanakan, ditinjau dan disesuaikan) dengan hasil kerja telah ditentukan, dikendalikan dan dipelihara dengan tepat. Rekomendasi yang diberikan untuk mewujudkan capability level yang diharapkan dengan meningkatkan penerapannya dan menambahkan pendayagunaan arsitektur TI yang memiliki fungsi pencatatan aset beserta sarana komputer. Hal tersebut dipergunakan untuk pengelolaan TI dengan sistematis dan memudahkan aktivitas perawatan secara teratur [25].

Fajarwati dkk (2018) menerapkan COBIT 5 untuk mengevaluasi tata kelola IT Pada Kantor Camat Baturraden, dengan fokus evaluasi pada level tata kelola. Penelitian ini memiliki target capability level 4 (predictable process) yang artinya prosedur dibangun sebelumnya sudah beroperasi pada batasan yang ditentukan untuk memperoleh hasil proses yang diharapkan, pada domain EDM05 dan EDM03. Sedangkan domain EDM01 dan EDM02 ditargetkan terdapat dalam capability level 3 (established process) yang mengartikan pengelolaan pada proses sebelumnya telah diaplikasikan menggunakan prosedur yang sudah ditetapkan, yang dapat memperoleh hasil proses yang diharapkan. Adapun hasil penelitian menunjukan EDM01, EDM02, EDM03 dan EDM05 tidak mencapai target dan terdapat dalam capability level 1 (performed process) yang artinya prosedur yang diaplikasikan berhasil memperoleh tujuan. Rekomendasi yang diberikan untuk mencapai target capability level dengan menciptakan SOP dan menyusun kelengkapan pada tata kelola teknologi informasi sesuai tujuan, diawali dari proses yang mempunyai dampak besar pada instansi [26].

Penelitian selanjutnya penerapan COBIT 5 fokus pada level pengelolaan serta manajemen dilakukan oleh Rahmadayanti (2019) Optimalisasi Pengelolaan Teknologi Informasi yang berada pada Sekolah Tinggi Teknologi Pagar Alam pada sektor instansi pendidikan dengan menerapkan COBIT 5 fokus pada level pengelolaan serta manajemen. Penelitian ini memiliki target maturity level 5 (optimised)

I.B.A.E.M. Putra : Tata Kelola Teknologi Informasi... menunjukan bahwa perusahaan telah menerapkan pengelolaam teknologi informasi yang mengacu kepada best practice. Selanjutnya penelitian menunjukan 9 domain berada pada maturity level 2 (repeatable) yang artinya ditemukan pola berulang dilakukan pada manajemen mengenai aktifitas tata kelola IT, tetapi eksistensinya belum terdefinisi dengan baik serta formal sehingga bersifat tidak formal yakni EDM04, BAI04, BAI10, APO01, APO04, APO07, MEA01, DSS01, serta DSS03, kesenjangan bernilai 3 terhadap target. Berikutnya dua domain berada pada maturity level 3 (defined) yang artinya ditemukan kebijakan baku formal dengan tertulis yang sudah disosialisasikan pada seluruh jajaran manajemen dan pegawai untuk dipatuhi serta dikerjakan pada aktifitas keseharian, yakni APO03 beserta BAI09 dengan kesenjangan bernilai 2 terhadap target. Dapat dinyatakan bahwa nilai maturity level tata kelola teknologi informasi tidak mencapai target. Secara keseluruhan untuk mencapai maturity level yang diharapan dibutuhkan prosedur pemulihan pengelolaan teknologi informasi yang berada pada Sekolah Tinggi Pagar Alam bahwa proses serta kegiatan harus didefinisikan, didokumentasikan, distandarisasi dan diintegrasikan [27].

Aji dkk (2019) melaporkan penggunaan COBIT 5 untuk mengevaluasi sistem informasi Rumah Sakit Ananda Purwokerto pada sektor instansi kesehatan fokus pada level tata kelola dan level manajemen. Penelitian ini memiliki tujuan dalam menganalisis tingkat penerapan pengelolaan teknologi informasi dengan menargetkan capability level 5 (optimized process) menunjukkan bahwa proses tersebut terus berkembang untuk mencapai tujuan bisnis saat ini serta masa yang akan datang. Rata-rata domain EDM dan APO adalah 3.12, yang merupakan level kapasitas 3 (established) sehingga terdapat kesenjangan bernilai 2 terhadap target. Adapun temuan dalam penelitian ini adalah tidak adanya dokumentasi berupa aturan/SOP/peraturan merupakan masalah disemua domain. Kemudian kurangnya kegiatan pelatihan dan tidak adanya proses perencanaan terhadap resiko yang kemungkinan terjadi serta kurang terjaganya keamanan merupakan temuan yang terdapat pada RS Ananda. Rekomendasi yang diberikan dengan melakukan dokumentasi terhadap segala jenis aturan/SOP/peraturan berkaitan dengan domain EDM serta APO. Memberikan pendidikan serta evaluasi kepada SDM dengan berkala kurun waktu minimal dua kali dalam setahun dengan tujuan menjamin kualitas SDM [28].

Sinta dkk (2019) mengevaluasi pengelolaan teknologi informasi yang terdapat di Bapenda Badung dengan memakai COBIT 5 fokus evaluasi pada level pengelolaan serta manajemen. Berdasarkan hasil analisa dan evaluasi rata-rata bernilai 3.30 menunjukan terdapat dalam capability level 3 (established) yang artinya pengelolaan proses sebelumnya telah diaplikasikan menggunakan prosedur yang sudah ditetapkan, yang dapat memperoleh hasil proses yang diharapkan. Sedangkan harapan target terdapat dalam capability level 5 (optimising process) dengan harapan proses tersebut akan terus diperbaiki untuk mencapai tujuan bisnis

p-ISSN:1693 - 2951; e-ISSN: 2503-2372 
saat ini serta masa yang akan datang. Sehingga kesimpulannya pada pelaksanaan evaluasi tersebut terdapat kesenjangan capability level proses TI diharapkan oleh manajemen dengan rata-rata bernilai 1.70. Untuk mencapai capability level harapan rekomendasi yang diberikan dengan melaksanakan pelatihan rutin dari pihak pengelola teknologi informasi Badan Pendapatan Daerah Badung kepada admin yang menggunakan tata kelola teknologi informasi dalam meminimalisir resiko terjadinya kesalahan. Mengembangkan sistem informasi pada Badan Pendapatan Daerah Badung dengan tampilan user friendly agar mudah digunakan oleh staff [3].

Budiarta dkk (2016) menggunakan COBIT 5 dalam audit proses bisnis pada divisi pengembangan sistem informasi pada sektor pendidikan STIMIK STIKOM BALI fokus pada level tata kelola dan level manajemen. Adapun target terdapat dalam capability level 4 (predictable process) yang artinya prosedur dibangun sebelumnya sudah beroperasi pada batasan yang ditentukan untuk memperoleh hasil proses yang diharapkan. Hasil audit menunjukan rata-rata pencapaian bernilai 2.67 berada pada capability level 3 (established). Dilihat terdapat kesenjangan bernilai 1 level yang artinya capability level tidak mencapai target. Berdasarkan capability level diatas dapat dinyatakan layanan proses bisnis pada STIKOM Bali menurut kepatuhan internal serta eksternal berdasarkan standar sudah ditetapkan, dengan prosedur yang terdapat pada divisi pengembangan sistem informasi. Rekomendasi yang diberikan untuk mencapai capability level yang menjadi harapan dengan mewujudkan sistem peninjauan dan evaluasi sesuai menurut proses bisnis dalam mengoptimalkan proses teknologi informasi [9].

Devanti dkk (2019) melakukan audit tata kelola teknologi informasi pada sektor bisnis penjualan barang khusus sepeda motor PT. Bisma Tunas Jaya Sentral dengan menggunakan COBIT 5 fokus pada level pengelolaan serta manajemen. Penelitian ini menargetkan berada pada maturity level 5 (optimized) menunjukan perusahaan sudah menerapkan pengelolaan teknologi informasi yang mengacu kepada best practice [29]. Tetapi, hasil yang diperoleh dari proses audit dengan nilai rata-rata 3.25 berada pada tingkat kematangan 3 (defined). Menunjukkan bahwa prosedur distandarisasi dan didokumentasikan dan kemudian dikomunikasikan dengan pelatihan. Prosedur tersebut belum lengkap akan tetapi telah meresmikan praktek yang berlangsung. Saran yang diberikan dengan tujuan penerapkan dalam pengelolaan teknologi informasi yang bagus guna mencapai target maturity level harapan dengan mewujudkan struktur organisasi dalam manajemen teknologi informasi sehingga ada penetapan tugas wewenang dengan tanggungjawab terstruktur. Menentapkan perencanaan strategis sehingga evaluasi atas kepatuhan dijadwalkan dengan efisien [30].

Setyaningrum dkk (2018) melaksanakan evaluasi manajemen risiko teknologi informasi (Enterprise Resource Planing) ERP-Portege pada sektor bisnis PT. Kimia Farma (Persero) Tbk memakai COBIT 5 fokus evaluasi pada pengelolaan serta manajemen. Adapun target yang ditetapkan berada pada capability level 3 (established) dalam domain EDM03 tentang ensure risk optimation yang artinya pengelolaan proses sebelumnya telah diaplikasikan menggunakan prosedur yang sudah ditetapkan, yang dapat memperoleh hasil proses yang diharapkan. Selanjutnya APO12 tentang managed risk dengan target capability level 2 (managed process) menunjukan prosedur yang sudah dijalankan dan diterapkan secara teratur (direncanakan, ditinjau dan disesuaikan) dengan hasil kerja telah ditentukan, dikendalikan dan dipelihara dengan tepat. Hasil audit menunjukan domain EDM03 terdapat dalam capability level 2. Selanjutnya pada domain APO12 (managed risk) berada pada capability level 1 (performed process) secara keseluruhan tidak mencapai target. Mengenai kurangnya sebagian proses belum didokumentasikan dengan lengkap selanjutnya dokumen perencanaan terhadap manajemen resiko juga tidak tersedia dengan lengkap. Temuan audit menjelaskan tidak terdapat tim manajemen maupun bagian khusus dalam penanganan dan pengelolaan segala jenis resiko TI. Sehingga rekomendasi agar mampu mengelola manajemen resiko teknologi informasi dengan baik, yaitu dengan membuat dokumen dimulai dari proses identifikasi terhadap resiko, analisis resiko, evaluasi terhadap resiko, beserta pengendalian resiko dalam memudahkan manajemen resiko dan kontrol pengelolaan resiko teknologi informasi [31].

Berlianna dkk (2018) menerapkan COBIT 5 dalam mengevaluasi tingkat kapabilitas sumber daya teknologi informasi dalam sektor instansi pendidikan Institut Teknologi Nasional Malang fokus pada level tata kelola dan manajemen. Penelitian ini menunjukan bahwa ITN berada pada capability level 1 (performed process) untuk domain EDM04 (ensure resource optimisation) sedangkan domain BAI09 (manage assets) dan domain DSS01 (managed operation) juga berada pada capability level 1. Hasil audit ini menunjukan bahwa proses sudah diimplementasikan serta sukses dalam mencapai tujuan. Kemudian peneliti menargetkan perbaikan terdapat dalam capability level 2 (managed process) memiliki prosedur yang diterapkan dimana terdapat perencanaan dan pemantauan pada setiap proses. Rekomendasi untuk mencapai target level 2 antara lain dengan mewujudkan perencanaan pengelolaan sumber daya TI dengan prosedur standar sebagai pedoman untuk melindungi sumber daya TI. Merealisasikan perencanaan manajemen sumber daya manusia dengan mewujudkan laporan hasil kinerja pegawai pada saat menjalankan tugasnya [32].

Suryono dkk (2018) memakai COBIT 5 dalam audit pengelolaan teknologi informasi e-skp (elektronik sasaran kinerja pegawai) pada sektor pemerintahan Balai Besar Perikanan Budidaya Laut yang berada pada daerah Lampung fokus pada level pengelolaan dan manajemen. Hasil evaluasi pada peneltian ini menunjukan domain EDM03, BAI06, MEA01, MEA02 DSS01, DSS02, DSS03, DSS05, APO12, dan APO13, dengan rata-rata bernilai 2.8 berada pada maturity level (defined process) dan tidak mencapai target maturity level 4 (managed) yang artinya terdapat kebijakan tertulis formal yang telah disosialisasikan pada semua tingkatan manajemen dan pegawai yang harus diikuti dan dilaksanakan dalam kegiatan sehari-hari. Beberapa kelemahan yang paling mematikan adalah tidak adanya standar prosedur pengamanan data dan informasi. Rekomendasi yang diberikan dalam memperbaiki dari sisi keamanan tata kelola teknologi informasi untuk mencapai maturity level target yaitu menyediakan fasilitias memadai dalam pengamanan data meliputi membangun ruangan khusus, membatasi hak akses 
terhadap ruangan, dan melaksanakan pemeriksaan dengan rutin atas resiko yang mungkin terjadi [33].

Nugraha dkk (2018) menggunakan COBIT 5 dalam menyusun kerangka kerja pengelolaan infrastruktur teknologi informasi dan komputer pada sektor pemerintahan di Kabupaten Badung. Dalam penelitian ini dijelaskan domain proses COBIT 5 yang dapat dipergunakan menjadi prinsipprinsip dalam pengelolaan infrastruktur teknologi informasi. Adapun domain terpilih sejumlah tiga belas domain proses yaitu EDM01 dalam memastikan pengaturan beserta perlindungan kondisi kerja tata kelola, EDM02 untuk memastikan pencapaian dan manfaat, EDM04 menentukan optimasi pada sumber daya, APO01 pengendalian kerangka kerja manajemen teknologi informasi, APO02 pengendalian strategi, APO03 pengendalian arsitektur perusahaan, APO07 pengendalian SDM, APO08 manajemen hubungan, BAI02 pengelolaan definisi persyaratan, BAI04 pengendalian ketersediaan beserta kapasitas, DSS01 tentang pengelolaan operasi dan DSS03 berkaitan dengan pengelolaan masalah. Rekomendasi dalam penyusunan kerangka kerja pengelolaan infrastruktur teknologi informasi dengan merealisasikan (Standard Operational Procedure) SOP berhubungan dengan manajemen infrastruktur TIK mulai dari pengamanan data, pengawasan, perlindungan integritas data, operasional layanan infrastruktur teknologi informasi dan sumber daya manusia [34].

Fernando dkk (2017) melakukan audit kinerja kepada sebuah sistem informasi dalam penelusuran tentang perkara yang dilakukan di Pengadilan Agama yang berlokasi pada Tanjung Karang Kelas I A dan terletak pada daerah Kota Bandar Lampung, dengan fokus pada level tata kelola dan level manajemen. Penelitian ini memiliki target maturity level 5 menunjukan perusahaan sudah menerapkan pengelolaan teknologi informasi mengacu kepada best practice. Namun hasil audit menunjukan domain EDM03 dan DSS03 terdapat dalam maturity level 3 (defined process) yang artinya terdapat kebijakan tertulis formal yang telah disosialisasikan pada semua tingkatan manajemen serta staf, untuk dipatuhi dan diimplementasikan dalam pekerjaan sehari-hari. Sedangkan domain DSS01, DSS02, DSS05, APO01, APO11, APO12, BAI06, MEA01 serta MEA02 berada pada maturity level 4 (managed and measureabel), yang artinya perusahaan sudah mempunyai beberapa indikator ataupun ukuran kuantitatif yang menjadi objektif ataupun sasaran kinerja setiap keberadaan implementasi teknologi informasi. Rekomendasi yang diberikan untuk mencapai target maturity level adalah memaksimalkan kemampuan sistem informasi, pengembangan sistem informasi dengan rutin dan monitoring [35].

Gamaliel dkk (2017) menggunakan COBIT 5 untuk pengukuran tingkat keselasaran pengelolaan teknologi informasi Pemerintah Sulawesi Utara, dengan fokus pada level tata kelola dan manajemen. Penelitian ini menunjukan domain APO01, APO03, BAI04, BAI09, BAI10 dan DSS01 berada pada capability level 0 (incomplete process) dan tidak

I.B.A.E.M. Putra : Tata Kelola Teknologi Informasi... mencapai target capability level 1 (performed process). Hasil ini menunjukan prosedur tidak diaplikasikan atau dapat dinyatakan gagal untuk mencapai target. Kemudian domain EDM04, APO04, APO07, DSS03 dan MEA01 berada pada capability level 1 dan tidak mencapai target capability level 2 (managed process). Untuk mencapai target kemampuan level tentunya diberikan rekomendasi perbaikan dengan membuat rencana strategi teknologi informasi terdiri dari data, informasi, teknologi, aplikasi dan proses bisnis berorientasi menciptakan strategi TI dan strategi organisasi dengan efektif dan efisien. Menyusun tim audit teknologi informasi internal untuk melaksanakan penilaian secara rutin dalam pemanfaatan fasilitas yang berfokus pada penerapan IT [36].

Maskur dkk (2017) menggunakan COBIT 5 dalam penerapan pengelolaan teknologi informasi yang terdapat pada Badan Penanaman Permodalan serta Pelayanan Terpadu Satu Pintu di daerah Kabupaten Bone Bolango, dengan fokus pada level tata kelola dan manajemen. Penelitian ini memiliki target capability level 3 (established process) yang artinya pengelolaan proses sebelumnya telah diaplikasikan menggunakan prosedur yang sudah ditetapkan, yang dapat memperoleh hasil proses yang diharapkan. Adapun hasil penelitian menunjukan domain APO01 dan BAI10 terdapat dalam capability level 1 (performed process) dengan kesenjangan bernilai 2 dari target. Hasil tersebut menunjukan prosedur yang diaplikasikan berhasil memperoleh tujuan. Sedangkan domain EDM04, DSS01, DSS03, APO03, APO04, APO07, BAI04, BAI09, dan MEA01 terdapat dalam capability level 2 (managed process) dengan kesenjangan bernilai 1 dari target. Hasil tersebut menunjukan prosedur yang sudah dijalankan dan diterapkan secara teratur (direncanakan, ditinjau dan disesuaikan) dengan hasil kerja telah ditentukan, dikendalikan dan dipelihara dengan tepat. Rekomendasi perbaikan yang diberikan untuk mencapai target capability level adalah melaksanakan serangkaian implementasi dasar perbaikan prosedur untuk mewujudkan serangkaian hasil kerja untuk mencapai level yang diharapkan. Menjaga keberlangsungan tata kelola teknologi informasi dengan dukungan kebijakan-kebijakan dari Pejabat pada instansi terkait [37].

Utami dkk (2019) menggunakan COBIT 5 untuk mengevaluasi manajemen SDM IT yang berada pada Dinas Komunikasi serta Informatika yang berada pada daerah Kota Batu, dengan fokus evaluasi pada level manajemen serta tata kelola. Penelitian ini memiliki target capability level 2 (managed process) yang mengartikan bahwa prosedur yang sudah dijalankan dan diterapkan secara teratur (direncanakan, ditinjau dan disesuaikan) dengan hasil kerja telah ditentukan, dikendalikan dan dipelihara dengan tepat. Sedangkan domain APO07 ditargetkan terdapat dalam capability level 3 (established process) mengartikan bahwa pengelolaan proses sebelumnya telah diaplikasikan menggunakan prosedur yang sudah ditetapkan, yang dapat memperoleh hasil proses yang diharapkan. Adapun hasil penelitian menunjukan domain EDM04 terdapat dalam capability level 1 (performed process)

p-ISSN:1693 - 2951; e-ISSN: 2503-2372 
dengan ksesenjangan bernilai 1 dari target. Hasil ini menunjukan prosedur yang diaplikasikan berhasil memperoleh tujuan. Sedangkan domain APO07 berada pada capability level 2 dengan kesenjangan bernilai 1 dari target. Rekomendasi yang diberikan untuk mencapai target capability level dengan merealisasikan dokumen information technology master plan dalam mendukung prosedur optimalisasi sumber daya. Menentukan SOP yang membantu pelaksanaan dari prosedur manajemen sumber daya manusia [38].

Octaviyanti dan Andry (2018) menggunakan COBIT 5 untuk audit suatu sistem enterprise asset management di perusahaan bergerak pada bidang pertambangan batubara, dengan fokus audit pada level tata kelola dan manajemen. Penelitian ini memiliki target capability level 4 (predictable process) mengartikan bahwa prosedur dibangun sebelumnya telah bekerja pada batas yang sudah ditentukan guna memperoleh hasil proses yang diinginkan pada domain EDM02. Sedangkan domain BAI06 dan BAI09 ditargetkan terdapat dalam level 3 (established process) yang mengartikan bahwa pengelolaan proses sebelumnya sudah diaplikasikan memakai prosedur yang sudah ditetapkan, yang dapat memperoleh hasil proses yang diharapkan. Adapun hasil penelitian menunjukan domain EDM02 berada pada capability level 3 dan tidak mencapai target dengan kesenjangan bernilai 1. Selanjutnya domain BAI06 dan BAI09 telah mencapai target berada pada capability level 3. Hasil ini menunjukan hampir keseluruhan prosedur mempunyai standar yang dijalankan dengan efektif. Rekomendasi yang diberikan untuk mencapai target capability level dengan prosedur optimasi nilai berkesinambungan secara konsisten dalam melaksanakan misi perusahaan. Mampu memberikan prediksi pada prosedur optimasi nilai dalam batasan yang sudah didefinisikan [39].

Ciptaningrum dkk (2015) mengunakan COBIT 5 untuk audit keamanan suatu sistem penginformasian yang berada pada Pemerintah Kota Yogyakarta, dengan fokus audit pada level tata kelola dan manajemen. Penelitian ini memiliki target berada pada capability level 3 (established process) yang artinya pengelolaan proses sebelumnya telah diaplikasikan menggunakan prosedur yang sudah ditetapkan, yang dapat memperoleh hasil proses yang diharapkan. Namun hasil audit menunjukan tidak mencapai target dan berada pada capability level 1 (performed process) dengan kesenjangan bernilai 1 . Adapun rincian pencapaian pada domain EDM03, APO12, APO13 dan BAI06 berada pada status (partialy achieved) sedangkan domain DSS05 berada pada status (largely achieved). Temuan hasil audit menunjukan bahwa kurangnya dokumentasi laporan dan standar operasional prosedur (SOP) mengenai strategi tentang keamanan sistem informasi sehingga tidak mampu mencapai nilai maksimal untuk pengukuran tingkat kemampuan keamanan sistem informasi. Rekomendasi yang diberikan untuk mencapai target capability level dengan mendokumentasikan strategi atau merealisasikan SOP untuk prosedur keamanan sistem informasi mengacu pada COBIT 5 guna keamanan informasi [40].

Noorrohman dkk (2018) mengevaluasi pengelolaan sumber daya TI dalam Dinas Komunikasi dan Informatika yang berada pada Kota Probolinggo, dengan fokus pada level pengelolaan serta manajemen. Penelitian ini memiliki target terdapat dalam capability level 2 (managed process) mengartikan bahwa prosedur yang sudah dilakukan dan diterapkan secara teratur (direncanakan, ditinjau dan disesuaikan) dengan hasil kerja telah ditentukan, dikendalikan dan dipelihara dengan tepat. Adapun hasil evaluasi menunjukan APO07, DSS01, BAI09 dan EDM04 terdapat dalam capability level 1 (performed process) yang artinya prosedur yang diaplikasikan berhasil memperoleh tujuan. Rekomendasi yang diberikan untuk mencapai target capability level dengan merealisasikan dokumentasi berhubungan dengan prosedur standar dalam manajemen SDM yang memenuhi parameter kompetensi sesuai tanggungjawab tugas yang dimiliki pegawai [41].

Naspati dkk (2018) menerapkan COBIT 5 untuk mengevaluasi pengelolaan sumber daya TI sebuah perusahaan PT. Infomedia Nusantara yang bergerak dalam bidang BPM serta CRM, dengan fokus evaluasi pada level tata kelola dan manajemen. Penelitian ini menargetkan terdapat dalam capability level 4 (predictable process) yang mengartikan bahwa prosedur dibangun sebelumnya telah bekerja pada batas yang sudah ditentukan guna memperoleh hasil proses yang diinginkan. Namun hasil evaluasi menunjukan terdapat dalam capability level 3 (established process) dengan kesenjangan bernilai 1 dari target. Hasil ini menunjukan bahwa pengelolaan proses sebelumnya telah diaplikasikan menggunakan prosedur yang sudah ditetapkan, yang dapat memperoleh hasil proses yang diharapkan. Rekomendasi yang diberikan untuk dapat berada pada capability level yang diharapkan dengan menghasilkan dokumen mengenai komunikasi dari kebijakan sumber daya. Melaksanakan mekanisme identifikasi terhadap kebutuhan informasi prosedur optimalisasi terhadap sumber daya. Mengidentifikasi mengenai penilaian prosedur manajemen sumber daya manusia dan mengumpulkan hasil kinerja proses, selanjutnya dipergunakan untuk mengontrol serta memverifikasi capaian atas kinerja proses [42].

Hasil review penelitian diatas menunjukan bahwa penerapan COBIT 5 dapat dilakukan pada lembaga pemerintahan, instansi pendidikan, instansi kesehatan atau Rumah Sakit dan Perusahaan. Pihak-pihak tersebut menerapkan COBIT 5 dengan tujuan yang sama yaitu menilai layanan teknologi informasi dapat memberikan hasil yang optimal pada suatu organisasi untuk mencapai tujuan manajemen. Beberapa organisasi ada yang menilai pada level manajemen ada pula yang menilai pada level tata kelola dan ada yang menilai dari level manajemen serta tata kelola. Hal tersebut berpengaruh terhadap kebutuhan organisasi untuk mencari tahu mengenai kemampuan level pengelolaan teknologi informasi yang diterapkan. Namun akan lebih baik apabila dapat menilai dari kedua sisi tata kelola dan manajemen untuk menyeimbangkan tujuan manajemen dengan proses teknologi informasi untuk menerapkan tata kelola teknologi informasi yang baik.

Layanan dalam mengelola teknologi informasi yang baik terkait kinerja teknologi informasi mampu memuaskan pengguna. Hal ini sangat penting melihat permasalahan pada review penelitian terletak pada kemampuan SDM dan kinerja teknologi informasi. Oleh karena itu dalam penelitian COBIT 5 akan lebih baik dikombinasikan dengan usability dengan metode user centered design untuk mengetahui tingkat kepuasan pengguna terhadap layanan teknologi informasi [43]. 
DOI: https://doi.org/10.24843/MITE.2021.v20i01.P01

Hasil tingkat kepuasan pengguna terhadap layanan teknologi informasi berhubungan dengan domain tata kelola untuk memastikan pemanfaatan teknologi informasi benar-benar memberikan hasil yang optimal dalam mencapai tujuan manajemen [44]. Sehingga panduan kontrol COBIT 5 memberikan hasil yang optimal sesuai dengan nilai kepuasan pengguna terhadap layanan teknologi informasi.

Berdasarkan review penelitian diatas menunjukan lembaga pemerintah yang paling produktif dalam menerapkan COBIT 5 ditunjukan pada gambar 3 diagram berikut. Apabila dibandingkan lembaga pemerintah yang mulai menerapkan sistem informasi manajemen sehingga perlu dilakukan audit. Oleh karena itu menimbulkan minat peneliti untuk melakukan research pada lembaga pemerintah dalam memberikan hasil evaluasi terhadap penerapan sistem informasi manajemen

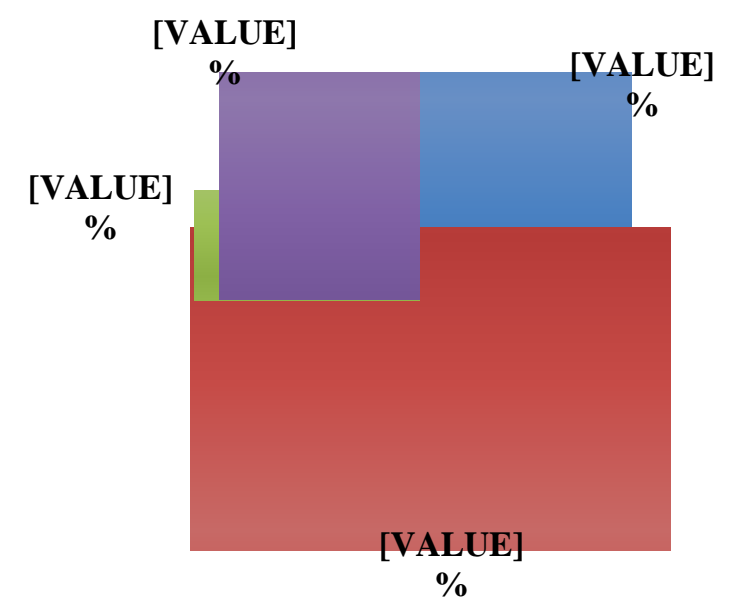

a Pendidikan $\square$ Pemerintah $\square$ Rumah Sakit $\square$ Perusahaan

Gambar 3. Diagram Penerapan COBIT 5

Terlihat pada Gambar 3, lembaga pemerintah berada pada posisi pertama dalam penerapan COBIT 5. Hal ini dipengaruhi dengan adanya penilaian inovasi pelayanan publik oleh Kemenpan-RB dan Peraturan Presiden No.95/2018 tentang SPBE. Sehingga pemerintah berkompetisi meningkatkan kinerja layanan dalam mengelola teknologi informasi, untuk mewujudkan manajemen pemerintah yang bersih, transparan, efektif dan akuntabel. Sehingga diperlukan untuk melakukan penilaian terhadap pengelolaan teknologi informasi pada lembaga pemerintah secara rutin. Sedangkan posisi kedua terdapat instansi pendidikan, posisi ketiga terdapat unit bisnis perdagangan kemudian dilanjutkan unit bisnis jasa dan kesehatan. Hal tersebut dipengaruhi penerapan dalam pengelolaan teknologi informasi yang lebih maju dan terintegrasi dengan proses bisnis. Lembaga swasta menerapkan COBIT 5 apabila dalam proses bisnis ditemukan ketidakseimbangan antara tujuan manajemen dan proses TI. Karena hal tersebut berpengaruh terhadap kinerja manajemen dalam menerapkan teknologi informasi. Selain itu lembaga

I.B.A.E.M. Putra : Tata Kelola Teknologi Informasi... pemerintah lebih terbuka untuk diteliti apabila dibandingkan dengan lembaga swasta yang sedikit tertutup.

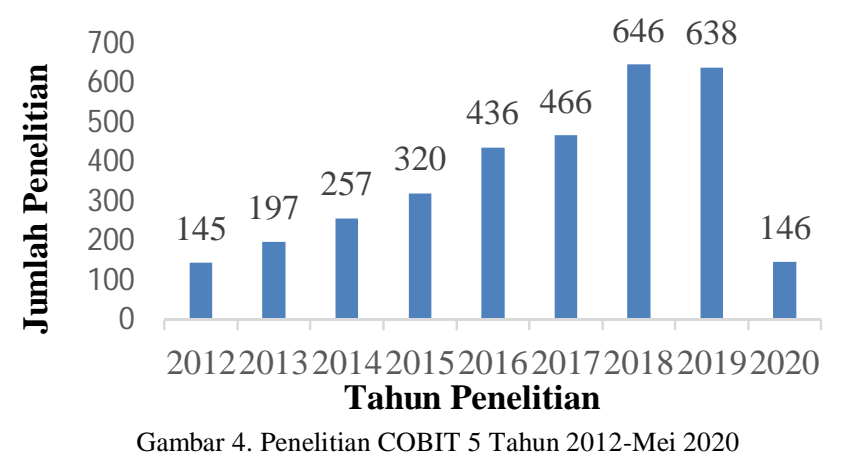

Berdasarkan penelitian COBIT 5 dari tahun 2012 sampai dengan Mei 2020 adapun dapat diketahui bahwa terjadi peningkatan jumlah penelitian pada setiap tahunnya terkait COBIT 5. Data tersebut bersumber laman pencarian penelitian Google Scholar dengan kata kunci penerapan COBIT 5 di Indonesia. Rata-rata pencapaian capability level pada lembaga pemerintah dan lembaga swasta bervariasi terdapat pada capability level 3 (established) dan level 4 (predictable process). Dan belum ada yang mencapai capability level 5 (optimized process).

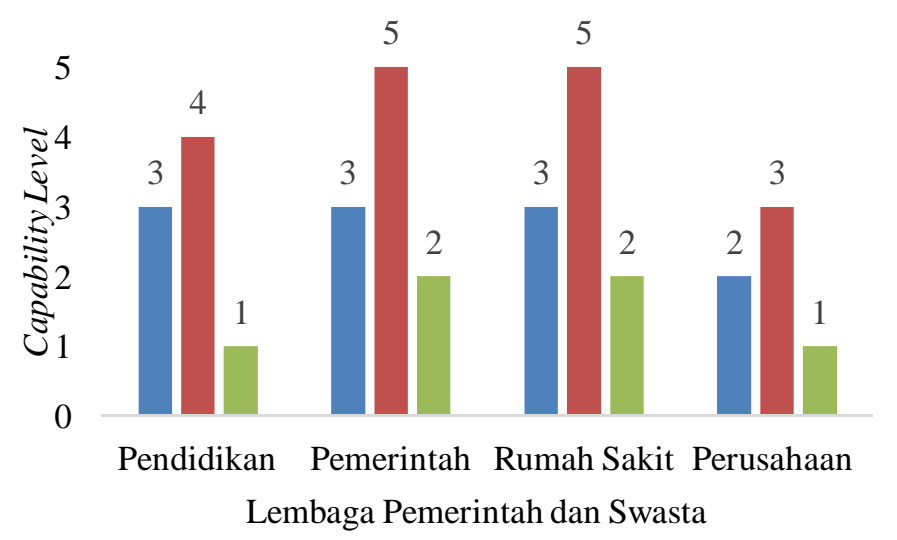

\footnotetext{
- Capability Level $\square$ Capability Level Target $\square$ Kesenjangan Gambar 5. Capability Level Rata-Rata COBIT 5 Lembaga Pemerintah \& Swasta
}

Dalam grafik ini menjelaskan lembaga pemerintah dan kesehatan ingin mencapai capability level 5 untuk proses yang optimal, sedangkan pada instansi pendidikan, unit bisnis perdagangan dan jasa menargetkan pencapaian secara bertahap sejalan dengan proses bisnis. Sehingga kesenjangan yang terjadi dapat dipenuhi secara bertahap. Hal-hal yang perlu diperhatikan untuk mencapai target capability level meliputi peningkatan kualitas SDM, mewujudkan standard operational procedure (SOP), optimaliasi kinerja teknologi p-ISSN:1693 - 2951; e-ISSN: 2503-2372 
informasi, pengelolaan resiko dan dokumentasi pada setiap proses bisnis. Untuk mencapai target capability level tentunya dapat dicapai secara bertahap dengan menjalankan rekomendasi penilaian sebelumnya untuk memperbaiki kekurangan tata kelola teknologi informasi pada organisasi [45].

Oleh karena itu penilaian dengan COBIT 5 perlu dilakukan secara rutin untuk mengetahui kualitas penerapan tata kelola teknologi informasi. Rekomendasi yang diberikan secara keseluruhan berfokus dalam pengendalian. Sehingga dapat menyelaraskan strategi bisnis dengan proses TI untuk kinerja tata kelola teknologi informasi yang bermutu. Namun rekomendasi tersebut tidak memberikan penerapan operasional.

\section{B. Agenda Penelitian}

Berdasarkan review diatas dalam penggunaan COBIT 5 untuk menilai tata kelola IT suatu lembaga/organisasi. Penulis sedang dalam proses penyusunan rencana penelitian untuk menilai dan menganalisa kinerja tata kelola IT pada instansi pemerintah Dinas Kependudukan serta Pencatatan Sipil Kota Denpasar dengan memakai kerangka kerja COBIT 5. Rencana penelitian akan melibatkan pejabat pemangku kepentingan pada objek penelitian sejumlah 20 orang. Kerangka kerja COBIT 5 dipilih karena memiliki keunggulan sebagai pedoman dalam menganalisa pengendalian manajemen proses untuk menerapkan tata kelola IT yang baik. Memiliki peran menjadi pedoman dalam memastikan rekomendasi perbaikan dalam menyeimbangkan strategi bisnis dengan proses teknologi informasi. Penilaian tersebut diharapkan untuk mencapai capability level pada level 3. Mendeskripsikan bahwa pengelolaan proses sebelumnya telah diaplikasikan menggunakan prosedur yang sudah ditetapkan, yang dapat memperoleh hasil proses yang diharapkan pada penerapan tata kelola teknologi informasi.

Pemerintah Kota Denpasar berkominten dalam pelayanan publik dengan motto Sewaka Dharma yang artinya adalah melayani merupakan kewajiban dalam meningkatkan kualitas pelayanan publik yang prima kepada masyarakat. Pada tahun 2017, 2018 dan 2019 Dinas Kependudukan dan Pencatatan Sipil Kota Denpasar mendapatkan penghargaan pelayanan publik dengan grade (A-) kategori 'sangat baik' oleh Kemenpan-RB Republik Indonesia [46]. Walaupun demikian, dilihat dari standar pelayanan minimal Dinas Kependudukan dan Pencatatan Sipil Kota Denpasar belum dapat memenuhi kepemilikan KTP-el untuk masyarakat Kota Denpasar dengan capaian presentase $100 \%$ dalam kurun waktu tiga tahun terakhir [47]. Oleh karena itu perlu dilaksanakan audit terhadap kinerja tata kelola teknologi informasi KTP-el untuk mengetahui kesenjangan antara strategi bisnis dan proses teknologi informasi di Kota Denpasar [48].

Tujuan penelitian ini adalah untuk menghasilkan rekomendasi mengenai perbaikan dalam menerapkan tata kelola TI KTP-el yang bagus untuk mencapai target standar pelayanan minimal dengan persentase $100 \%$ yang telah ditetapkan dan mencapai predikat pelayanan publik yang prima sesuai target yang diharapkan oleh Kemenpan-RB. Secara umum langkah-langkah penelitian penerapan COBIT 5 dalam menilai tata kelola teknologi informasi ditunjukan pada gambar 6 [49].

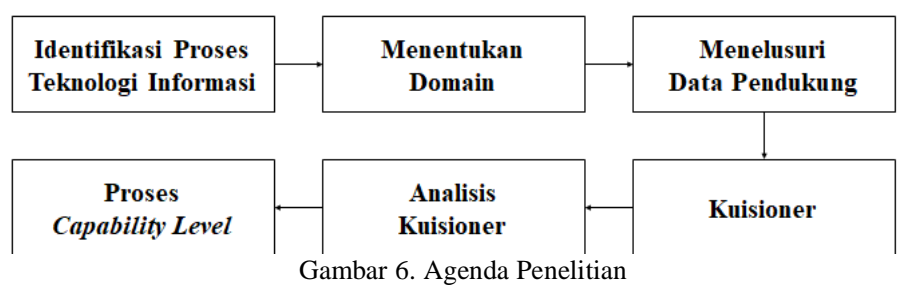

Dalam agenda penelitian ini tahapan pertama adalah mengidentifikasi proses IT di Dinas Kependudukan serta Pencatatan Sipil yang berada pada daerah Kota Denpasar. Tahap ini melakukan identifikasi pada proses teknologi informasi yang sedang dijalankan ditempat objek penelitian beserta kebutuhan stakeholder [50]. Setelah titik kritis permasalahan ditemukan kemudian menentukan domain COBIT 5 yang dipergunakan menurut permasalahan pada pemetaan tujuan bisnis serta proses IT yang berlangsung [51]. Untuk mendukung kegiatan penelitian tentunya diperlukan mekanisme mengumpulkan data [52]. Dokumentasi selanjutnya melakukan wawancara berkaitan dengan penelitian sebagai dasar untuk memperoleh tujuan penelitian [53].

Membagikan kuisioner pertanyaan-pertanyaan dengan sistematis dan logis sesuai dengan domain COBIT 5 menjadi arahan proses pengukuran dan evaluasi [54]. Berikutnya menganalisa kuisioner dengan mengulas dan evaluasi terhadap jawaban kuisioner yang sudah diberikan selanjutnya diolah untuk meningkatkan level tingkat kematangan [55]. Proses capability level adalah tahapan dimana menganalisa level pencapaian tingkat kematangan dalam proses teknologi informasi yang sedang berlangsung dengan level pencapaian tingkat kematangan yang menjadi harapan untuk mendapatkan nilai tingkat kesenjangan untuk proses teknologi informasi.

\section{KESIMPULAN}

Penelitian ini telah melakukan review terhadap penelitian penerapan kerangka kerja COBIT 5 dalam mencapai tujuan manajemen suatu organisasi di Indonesia. Sudah banyak instansi di Indonesia baik dari sektor pemerintah, pendidikan, dunia usaha atau bisnis berorientasi profit maupun organisasi non profit telah menerapkan kerangka kerja COBIT 5. Pencapaian tingkat capability level bervariasi bergantung pada kemampuan penerapan tata kelola teknologi informasi dalam tiap-tiap instansi atau organisasi. Rata-rata pencapaian capability level pada instansi atau lembaga yang dinilai oleh para peneliti diatas adalah pada level 3 (established process) yang menunjukkan bahwa proses sudah dilaksanakan dengan proses tertentu yang sudah ditentukan serta dapat memperoleh hasil yang diinginkan. Sementara target capability level ditetapkan pada level 4 (predictable process) dan level 5 (optimizing process) secara bertahap yang akan dapat dicapai apabila telah menjalankan rekomendasi pada pencapaian tahapan sebelumnya.

\section{REFERENSI}

[1] Pemerintah Republik Indonesia, Peraturan Menteri Komunikasi dan Informatika Nomor 23 Tahun 2012 Tentang Pemanfaatan Pembiayaan Teknologi Informasi dan Komunikasi Layanan Pita Lebar. Indonesia: 
Pemerintah Republik Indonesia, 2012.

[2] Sutarman, Pengantar Teknologi Informasi. Jakarta: Bumi Aksara, 2009.

[3] P. H. Sinta, I. P. A. Swastika, I. G. Lanang, and A. Raditya, "Kajian tata kelola TI berbasis COBIT 5 pada dinas pendapatan daerah kabupaten badung," Jutikomp., vol. 2, no 2, pp. 1-10, Okt. 2019.

[4] ISACA, A Business Development Company for Information Technology Management and Control. ISACA: United States of America. 2012.

[5] I. B. L. M. Suta, I. G. N. A. S. Mahendra, and M. Sudarma, "Application of COBIT 5 for revision of the information system for hospital services audit," Int. J. Eng. Emerg. Technol., vol. 3, no. 2, pp. 2-7, Jul. 2018.

[6] Pemerintah Republik Indonesia, Peraturan Presiden Republik Indonesia Nomor 95 Tahun 2018 Tentang Sistem Pemerintahan Berbasis Elektronik. Indonesia: Pemerintah Republik Indonesia, 2018.

[7] W. S. Cahyani, I. Darmawan, and R. Mulyana, "Perancangan sistem manajemen teknologi informasi berdasarkan studi kasus domain elektronik EDM COBIT 5 dinas komunikasi dan statistik informatika kabupaten bandung barat," in Proc. of Eng, 2019, pp. 8400-8406.

[8] A. P. Utoma, and N. Mariana, "Analisis manajemen TI bidang akademik dengan kerangka studi kasus COBIT di universitas semarang," J. Teknol. Inf. Din., vol. 16, no. 2, pp. 139-149, Jul. 2011.

[9] K. Budiarta, A. P. S. Iskandar, and M. Sudarma, "Development of an audit information system with COBIT 5 study framework stmik stikom bali,” Int. J. Eng. Emerg. Technol., vol. 1, no. 1, pp. 1-5, Jul. 2016.

[10] A. K. Darmawan, and A. D. Harto, "Analisis domain BAI, DSS dan MEA untuk mengukur kualitas layanan e-government di kabupaten pamekasan menggunakan framework COBIT 5.0," J. Buana Inform., vol. 10, no. 1, pp. 53-61, Apr. 2019.

[11] A. Mustofa, and S. W. Handani, "Mengukur kinerja sistem pengelolaan keuangan kantor kecamatan banyumas kecamatan kemranjen dengan kerangka kerja COBIT 5 pada domain MEA," J. Pro Bisnis., vol. 10, no. 2, pp. 58-71, Agu. 2017.

[12] R. Hermawan, and M. R. Pahlevi, "Evaluasi sistem pelayanan terpadu di kecamatan jawa timur menggunakan framework COBIT 5 di bidang delivery, service dan support," J. Manaj. Sist. Inf., vol. 4, no. 2, pp. 171-180, Jun. 2019

[13] S. D. Rehatta, and A. D. Manuputty, "Mengukur tingkat kematangan manajemen TI dalam implementasi sistem informasi manajemen kepegawaian menggunakan kerangka kerja COBIT 5 domain MEA di instansi daerah untuk pelatihan dan pendidikan staf kota salatiga," $J$. Inf. Syst. Informatics., vol. 1, no. 2, pp. 123-135, Sep. 2019.

[14] A.Y. Chairani, R. Afwani, and S. E. Anjawarni, "Analisis manajemen TI dalam peningkatan kualitas SDM di provinsi nusa tenggara barat, menggunakan framework COBIT 5," J-Cosine., vol. 3, no. 2, pp. 1-10, Des. 2019.

[15] A.A. M. D. Krisnandari, D. M. Wiharta, and N. P. Sastra, "Penerapan TI dalam reformasi birokrasi dalam pendidikan," Maj. Ilm. Teknol. Elektro., vol. 18, no. 2, pp. 287-292, Mei. 2019.

[16] A. Sumichan, I. M. G. Yudiyana, and I. M. Sudarma, "Audit with the COBIT 5 framework with a focus on DSS domains," Int. J. Eng. Emerg. Technol., vol. 3, no. 2, pp. 67-71, Jul. 2018.

[17] R. P. Aji, and Sarmini, "Kajian teknik manajemen TI di dinas kesehatan kabupaten banyumas mengacu pada framework COBIT 5," $J$. Pro Bisnis., vol. 12, no. 2, pp. 13-24, Agu. 2019.

[18] A. F. Wijaya, and A. T. Andani, "Evaluasi kinerja sistem pelaporan elektronik COBIT 5 di kantor pelayanan pajak pratama kota salatiga" $J$. Terap. Teknol. Inf., vol. 1, no. 1, pp. 61-70, Apr. 2017.

[19] S. Rohman, N. Aghita, and R. Afwani, "Analisa tata kelola teknologi informasi untuk kasus di dinas pariwisata prov. nusa tenggara barat menggunakan framework COBIT 5," JTIKA., vol. 2, no. 1, pp. 57-66, Des. 2019.

[20] Safriwal, "Rekomendasi peningkatan manajemen teknologi informasi dinas sosial dan tenaga kerja kabupaten solok dengan menggunakan COBIT 5," J. Masy. Telemat. dan Inf., vol. 8, no. 1, pp. 19-30, Jul. 2017

[21] R. Wahyuni, “'Evaluasi peningkatan sistem informasi akademik oleh COBIT 5 di STMIK hang tuah pekanbaru," J. Ilmu Komput., vol. 6, no. 2, pp. 91-96, Okt. 2017.

I.B.A.E.M. Putra : Tata Kelola Teknologi Informasi...
[22] A.W. Doni, and Y. Elda, "Analisis manajemen risiko informasi pada teknologi oleh COBIT 5.0 studi kasus pt. global infotechnology," $J$. Sehat Mandiri., vol. 13, no. 1, pp. 35-42, Mei. 2018.

[23] P. P. Thenu, A. F. Wijaya, and C. Rudianto, "'Analisis manajemen risiko TI dengan COBIT 5 studi kasus pt global infotechnology," $J$. Bina Komput., vol. 2, no. 1, pp. 1-13, Feb. 2020

[24] R. C. S. Hariyono, "Analysis and evaluation of information technologies for control processes with COBIT 5 in the EDM area of civilized university studies," Indones. J. Bus. Intell., vol. 1, pp. 1-7, Jun. 2018.

[25] S. Rizal, and M. Rasmila, "'Manajemen information technology di rumah sakit kusta dokter rivai abdullah palembang," Matrik., vol. 17, no. 3, pp. 237-246, Des. 2015.

[26] S. Fajarwati, S. Sarmini, and Y. Septiana, "Evaluasi tata kelola IT melalui kerangka COBIT 5," Juita J. Inform., vol. 6, no. 2, pp. 73-80, Nov. 2018.

[27] F. Rahmadayanti, W. Cholil, and L. Atik, "Optimalisasi pengelolaan teknologi informasi dengan studi kasus COBIT 5 pagar alam,” J. Bina Komput., vol. 1, no. 2, pp. 116-121, Jul. 2019.

[28] R. P. Aji, I. Setiawan, and Y. A. Wibowo, "Evaluasi sistem informasi rumah sakit ananda purwokerto dengan menggunakan domain EDM dan APO COBIT 5," J. Teknol. Inf. dan Multimed., vol. 1, no. 2, pp. 59-70, Feb. 2019.

[29] T. I. R. K. Dewi, Linawati, and I. M. O. Widyantara, "Audit prasarana pelayanan publik aplikasi di kota denpasar," Maj. Ilm. Teknol. Elektro., vol. 16, no. 2, pp. 78-83, Agu. 2017.

[30] K. Devanti, W. G. S. Parwita, and I. K. B. Sandika, "Pengendalian manajemen informasi menggunakan bingkai COBIT 5.0 untuk pt. BTJS," J. Sist. Inf. dan Komput. Terap. Indones., vol. 2, no. 2, pp. 6576, Des. 2019

[31] N. D. Setyaningrum, Suprapto, and A. Kusyanti, "Evaluasi manajemen risiko TI dengan studi framework COBIT 5 di pt chemical farm persero tbk, pabrik watudakon," J. Pengemb. Teknol. Inf. dan Ilmu Komput., vol. 2, no. 1, pp. 143-152, Jan. 2018

[32] S. N. S. Berlianna, Suprapto, and A. R. Perdanakusuma, "Evaluasi tingkat keterampilan sumber daya TI di institut teknologi nasional malang menggunakan framework COBIT 5," J. Pengemb. Teknol. Inf dan Ilmu Komput. Univ. Brawijaya., vol. 2, no. 10, pp. 3699-3702, Okt. 2018.

[33] R. R. Suryono, D. Darwis, and S. I. Gunawan, "Kajian pengelolaan TI menggunakan kerangka studi COBIT 5.0 pada pusat budidaya perikanan laut besar lampung," J. Teknoinfo., vol. 12, no. 1, pp. 16-22, Des. 2018.

[34] A. A. G. A. Nugraha, Linawati, and N. P. Sastra, "'Kerangka pengelolaan infrastruktur TIK di kab. badung," Maj. Ilm. Teknol. Elektro., vol. 17, no. 1, pp. 10-16, Jan. 2018

[35] Y. Fernando, R. B. Ilmillah, and D. Darwis, "Audit efisiensi sistem informasi perkara pengadilan agama kelas I Tanjung Karang, Bandar Lampung," J. Tekno Kompak., vol. 11, no. 1, pp. 18-23, Des. 2017.

[36] B. Gamaliel, Y. Rindengan, and S. Karouw, "Mengelola information technology melalui COBIT 5 di pemerintah sulawesi utara," E-Journal Tek. Inform., vol. 11, no. 1, pp. 1-8, Des. 2017.

[37] Maskur, N. Adolong, and R. Mokodongan, "Penerapan manajemen teknologi informasi menggunakan kerangka kerja COBIT $5.0 \mathrm{kab}$ bone bolango bpmptsp," J. Masy. Telemat. dan Inf., vol. 8, no. 2, pp. 109-126, Okt. 2017.

[38] P. R. Utami, W. H. N. Putra, and Suprapto, "audit pengelolaan SDM IT dalam rangka studi kasus COBIT 5 dinas komunikasi dan informatika kota batu,," J. Pengemb. Teknol. Inf. dan Ilmu Komput., vol. 3, no. 7, pp. 6583-6591, Jul. 2019.

[39] P. Octaviyanti, and J. F. Andry, "Audit of corporate governance systems using the COBIT 5 Framework," Ikraith-Informatika., vol. 2 no. 1, pp. 34-42, Mar. 2018.

[40] D. Ciptaningrum, E. Nugroho, and D. Adhipta, "Pengendalian keamanan informasi di kantor kota yogyakarta melalui COBIT 5," in Semin. Nas. Teknol. Inf. dan Komun, 2015 pp. 65-74.

[41] M. O. Noorrohman, Suprapto, and A. Rachmadi, "Evaluasi tata kelola sumber daya information technology di dinas komunikasi dan informatika probolinggo menggunakan framework COBIT 5," $J$.

p-ISSN:1693 - 2951; e-ISSN: 2503-2372 
Pengemb. Teknol. Inf. dan Ilmu Komput., vol. 2, no. 11, pp. 5928-5934, Nov. 2018.

[42] A. R. Naspati, Suprapto, and A. D. Herlambang, "Evaluasi pengelolaan sumber daya TI pengelolaan sumber daya TI dengan studi kasus COBIT 5 pt. infomedia nusantara," J. Pengemb. Teknol. Inf. dan Ilmu Komput., vol. 2, no. 11, pp. 5384-5393, Nov. 2018.

[43] M. M. Ahamed, and Z. B. A. Bakar, "The triangular model theory improves usability through a user-centered design process in humancomputer interaction" Int. J. Contemp. Comput. Res., vol. 1, no. 2, pp. 1-7, Jul. 2017.

[44] S. W. Ginting, and I. M. Sudarma, "Analisis kegunaan aplikasi sistem informasi destinasi wisata berbasis android di pulau ambon," JTIIK., vol. 7, no. 5, pp. 1061-1068, Okt. 2020.

[45] K. S. Utami, I. G. W. Darma, and M. Sudarma, “ Audit data warehouse system using COBIT 5 framework," Int. J. Eng. Emerg. Technol., vol. 3, no. 2, pp. 109-115, Jul. 2018.

[46] Dinas Kependudukan dan Pencatatan Sipil Kota Denpasar, Profil Dinas Kependudukan dan Pencatatan Sipil Kota Denpasar. Denpasar: Pemerintah Kota Denpasar, 2019.

[47] Pemerintah Kota Denpasar, Standar Pelayanan Minimal (SPM) 2019. Denpasar: Pemerintah Kota Denpasar, 2019.

[48] M.D. Mulyawan, R.S. Hartati, and Y. Divayana, "Audit sistem informasi kesiman kertalangu sikekal menggunakan COBIT 4.1," Maj. Ilm. Teknol. Elektro., vol. 19, no. 2, pp. 139-144, Jul. 2020.

[49] I.B.A.E.M Putra, R. S. Hartati, and Y. Divayana, "Audit sistem informasi e-show untuk kependudukan dan layanan pencatatan sipil di kota denpasar," Maj. Ilm. Teknol. Elektro., vol. 19, no. 1, pp. 107-112, Jan. 2020.

[50] M. D. P. Pramita, I. M. D. Pradipta, and I. M. Sudarma, "Audit divisi IT dalam proses pemeliharaan sistem internal oleh pt jamkrida bali mandara dengan software framework model pemeliharaan SMMM," Int. J. Eng. Emerg. Technol., vol. 2, no. 2, pp. 83-90, Jul. 2017.

[51] F.T. Prabowo, N.M.A.E.D. Wirastuti, and I.N.S. Kumara, "'Evaluasi layanan broadband menggunakan COBIT 4. 1," Maj. Ilm. Teknol. Elektro., vol. 16, no. 2, pp. 25-30, Mei. 2017.

[52] G. B. Subiksa, K. A. B. Permana, and M. Sudarma, " Audit an esignature public service project by knowledge quality management," Int. J. Eng. Emerg. Technol., vol. 2, no. 2, pp. 41-46, Jul. 2017.

[53] M. P. A. Ariawan, P. B. I. S. Putra, and I. M. Sudarma, "Analysis of business architecture design by TOGAF frames case study at the archives unit at the faculty of agricultural engineering at udayana university," Int. J. Eng. Emerg. Technol., vol. 2, no. 2, pp. 52-57, Jul. 2017.

[54] N.L.A. Laksmidewi, Linawati, and I.M.O. Widyantara, "Evaluasi sistem informasi manajemen kepegawaian oleh DS5 dan DS9 COBIT 4. 1 studi kasus pemerintah provinsi bali," Maj. Ilm. Teknol. Elektro., vol. 17, no. 1, pp. 25-32, Jan. 2018.

[55] I.K.N.A. Jaya, I.M.O. Widyantara, and R.S. Hartati, "Audit pengelolaan sumber daya dan ukuran kinerja sistem informasi akademik universitas hindu indonesia menggunakan kerangka kerja COBIT 4. 1," Maj. Ilm. Teknol. Elektro., vol. 18, no. 1, pp. 35-40, Jan. 2019. 